\title{
КОМУНІКАТИВНІ БАР'СРИ НАЦІОНАЛЬНОЇ ТА ГРОМАДЯНСЬКОЇ САМОІДЕНТИФІКАЦІЇ МОЛОДІ В РІЗНИХ ПІДСИСТЕМАХ СОЦІАЛЬНОЇ ВЗАСМОДІї
}

Аналізуються результати емпіричного дослідження комунікативних бар'єрів національної та громадянської самоідентифікації молоді, що здійснювалося за допомогою методів глибинного інтерв'ю, методики “Хто я?”, методики виявлення ціннісних орієнтацій та репертуарних рангових решіток. Визначено критерії та індикатори різних типів комунікативних бар'єрів (соціальних, інформаційно-ідеологічних, індивідуально-психологічних, змістових та операціональних). Виявлено підсистеми соціальної взаємодії, в яких відбувається процес національної та громадянської самоідентифікації молоді: найближче соціальне оточення (друзі); одногрупники; родина; викладачі; друзі $з$ інших країн; соціальні медіа (соцмережі: Facebook, Instagram, Telegram, Twitter); традиційні медіа (новини в інтернеті, телевізійні новини); культурно-мистецькі твори (літературні і музичні) та їх виконавці (актори та персонажі кінематографа, музиканти, танцівники). Означено домінуючі бар'єри національної та громадянської самоідентифікації. Запропоновано технологічну схему подолання комунікативних бар'єрів національної та громадянської самоідентифікації шляхом їх актуалізації (технології діагностики: розпізнавання бар'єрів, визначення їхнього впливу на самоідентифікацію, визначення референтних груп впливу на самоідентифікацію), рефлексії (рефлексивні технології: оцінка багатоплановості виявів у підсистемах соціальної взаємодії, визначення зон комфорту/дискомфорту, оцінка адекватності власної поведінки, рефлексія можливих стратегій поведінки), трансформування в різних підсистемах соціальної взаємодії (технології перетворення: створення мотивації до трансформації власного комунікативного досвіду, оволодіння вміннями і навичками оптимізації міжособової взаємодії) та інтеграції досвіду (технології концептуалізації досвіду: закріплення мотивації до аутокорекції і трансформації набутого досвіду, розвиток готовності застосовувати нові знання, вміння та навички в реальній соціальній взаємодії).

Ключові слова: комунікативні бар'єри, національна самоідентифікація, громадянська самоідентифікація, соціальна взаємодія.

I. V. Ostapenko

\section{COMMUNICATIVE BARRIERS OF YOUTH'S NATIONAL AND CIVIC SELF-IDENTIFICATION IN VARIOUS SUBSYSTEMS OF SOCIAL INTERACTION}

It is analyzed the results of empirical study of national and civic self-identification communicative barriers of young people, which was carried out by the method of indepth interviews, the "Who am I?" technique, the technique for value orientations' identification and repertoire ranked grids. Criteria and indicators of various types of communicative barriers (such as social, information-ideological, individual psychological, content and operational ones) are determined. There are revealed the subsystems of 
social interaction in which the process of self-identification of young people is taking place: the nearest social group (friends); group members; family; teachers; friends from other countries; social media (Facebook, Instagram, Telegram, Twitter); traditional media (Internet news, television news); cultural and artistic works (fiction, cinema and music) as well as art performers (actors, musicians, dancers). The dominant barriers of national and civic self-identification were defined. It was proposed the technological scheme to overcome the communicative barriers of national and civic self-identification through their actualization (diagnostic technologies: recognition of barriers, determination of their influence on self-identification, determination of reference groups of influence on self-identification), through their reflection (reflexive technologies: estimation of manifestations multiplicity in subsystems of social interaction, determination of comfort / discomfort zones, estimation of own behavior adequacy, reflection of possible behavior strategies), transformation into various subsystems of social interaction (technologies of transformation: motivation for the own communicative experience transformation, mastering of optimization skills on interpersonal interaction) and experience integration (technologies of experience conceptualization: consolidation of motivation to auto-correction and transformation of the acquired experience, development of readiness to apply new knowledge, skills and abilities in real social interaction).

Key words: communicative barriers, national self-identification, civic selfidentification, social interaction.

Постановка проблеми. Становлення національної та громадянської ідентичності молоді належить до кола проблем, які викликають підвищений інтерес з боку сучасних дослідників. При вивченні цієї проблематики особливу увагу науковців привертають процеси самоідентифікації та чинники, що зумовлюють набуття тієї чи іншої ідентичності. Процеси комунікації і самоідентифікації щільно пов’язані та взаємозумовлені, оскільки ідентифікація себе і презентація себе іншим є умовами комунікації та спільної діяльності людей і, відповідно, комунікація - формувальний процес, що безпосередньо впливає на зміст і характер самоідентифікації. Комунікація - процес, у ході якого ми конструюємо не тільки свою соціальну реальність, а й своє власне “я". I коли в процесі комунікації відбувається викривлення смислів, виникають комунікативні бар'єри, які ми розуміємо як утруднення або перешкоди для ефективного спілкування. Особливості вияву комунікативних бар'єрів, що мають місце в процесі національної та громадянської самоідентифікації, вивчено недостатньо, що зумовлює актуальність нашого дослідження.

Аналіз останніх досліджень та публікацій. Теоретико-методологічною основою для вивчення особливостей національної та громадянської самоідентифікації слугують положення, ідеї та концепції, представлені в сучасних дослідженнях з цієї проблематики. Насамперед це ідеї про інтеграцію всіх ідентифікацій, набутих особистістю в процесі соціалізації; положення про провідні риси національної ідентичності, 
до яких відносять: усвідомлення своєї належності до держави; концепції спільної масової і громадянської культури як чинників розвитку національної та громадянської ідентичності; положення про індивідуальний і груповий характер процесу громадянської ідентичності; положення про провідну роль комунікації в процесі самоідентифікації особистості в різних ситуаціях реальної соціальної взаємодії; положення про активізаційну функцію комунікативних бар'єрів у процесі самоідентифікаціï [1-4].

Не вирішені раніше частини загальної проблеми. У контексті досліджуваної проблеми додаткового вивчення потребують особливості впливу комунікативних бар'єрів на самоідентифікацію молоді в різних підсистемах соціальної взаємодії, а також можливі напрями трансформації комунікативних бар'єрів для створення сприятливих умов активізації процесів національної та громадянської самоідентифікації молоді.

Мета статті - висвітлення особливостей вияву і напрямів трансформації комунікативних бар'єрів національної та громадянської самоідентифікації молоді в різних підсистемах соціальної взаємодії.

Виклад основного матеріалу дослідження. Досліджуючи особливості самоідентифікації, ми, як і багато інших дослідників, використовували для вивчення змістових характеристик національної та громадянської самоідентифікації молоді методику "Хто я?" М. Куна і Т. Макпартленда. Цю методику було модифіковано та апробовано; відповідно, розширено перелік базових питань для визначення афективних і конативних особливостей особистісної самоідентифікації та когнітивних, афективних i конативних особливостей групової самоідентифікації. Модифікуючи зазначену методику, ми спиралися на підхід, запропонований Т. Румянцевою [5].

Дослідження за допомогою методики “Хто я?" проводилося протягом 2017 р. у вищих навчальних закладах м. Києва серед студентів, які навчаються за спеціальностями технічного, природничого та гуманітарного профілів (загальний обсяг вибірки - 130 осіб, 3 них 72 особи жіночої статі і 58 - чоловічої).

У цілому уявленням молоді про себе властиві досить високий рівень диференційованості, позитивна валентність "Я-ідентифікацій" та “Ми-ідентифікацій”, амбівалентність “Вони-ідентифікацій”, домінування референтних груп з найближчого соціального оточення (родина, друзі, “однокашники”), які забезпечують простір життєвої самореалізації. На основі аналізу результатів дослідження за методикою “Хто я?” було визначено особливості національної самоідентифікації студентської молоді:

- зростання ступеня значущості національної самоідентифікації в просторі "Ми-ідентифікацій” порівняно з простором "Я-ідентифікацій” (“українці" - на 3-му місці за частотою згадування, тоді як “українець”, "українка" - на 7-му); 
- позитивна валентність ідентифікаційних характеристик, пов'язаних з національною самоідентифікацією;

- домінування лінгвістичних форм (насамперед дієслів теперішнього часу), що свідчить про активне і свідоме ставлення до себе як представника політичної нації (у просторі “Я-ідентифікацій” і “Ми-ідентифікацій”) та інших соціальних груп (простір “Вони-ідентифікацій”);

- наявність внутрішньоукраїнських соціальних груп 3 негативною валентністю в просторі “Вони-ідентифікацій” (влада, політики крадуть, грабують), які слугують об'єктом для порівняння з “Ми-ідентифікаціями” і “Я-ідентифікаціями”.

Також у процесі аналізу даних за методикою “Хто я?” було з'ясовано такі особливості громадянської самоідентифікації студентської молоді:

- зростання ступеня значущості громадянської самоідентифікації в просторі "Ми-ідентифікацій” порівняно з простором “Я-ідентифікацій" (однак менш істотне порівняно з національною самоідентифікацією);

- позитивна або нейтральна валентність ідентифікаційних характеристик, пов'язаних з громадянською ідентичністю (що можна розглядати як свідчення ії меншої значущості для молоді порівняно 3 національною ідентичністю);

- домінування лінгвістичних форм (насамперед дієслів теперішнього часу), що свідчить про активне і свідоме ставлення до себе як громадянина (у просторі “Я-ідентифікацій” і “Ми-ідентифікацій”) та інших соціальних груп (простір “Вони-ідентифікацій”) аналогічно $з$ національною ідентичністю;

- наявність внутрішньоукраїнських соціальних груп з негативною валентністю в просторі “Вони-ідентифікацій” (влада, політики - крадуть, грабують), які слугують об' єктом для порівняння та зіставлення з “Миідентифікаціями” і “Я-ідентифікаціями” (аналогічно з національною ідентичністю).

Помітною $є$ схожість наведених особливостей національної та громадянської самоідентифікації, що може свідчити про їхню недостатню диференціацію в уявленнях студентської молоді про себе. Крім того, виявлені розбіжності щодо валентностей можуть свідчити про те, що національна самоідентифікація $є$ більш стійким утворенням порівняно з громадянською.

Щоб виявити ціннісні орієнтації, що є регулятором національної та громадянської самоідентифікації молоді, було створено відповідну методику на основі використання незавершених речень. При цьому ми спиралися на положення диспозиційної концепції В. Ядова, у межах якої поєднуються: 1) цінності-ідеали (бажання); 2) цінності-норми (зобов'язання); 3) цінності-цілі (прагнення): 4) цінності-засоби (способи досягнення) [6]. 
Для визначення цінностей-ідеалів ми намагалися з'ясувати, чого молоді люди хочуть як українці та громадяни; для визначення цінностейнорм - що обстежувані повинні/мають робити як українці і громадяни; цінностей-цілей - чого вони мають прагнути як українці і громадяни; цінностей-засобів - як і за рахунок чого вони досягають своїх цілей як українці і громадяни.

Результати дослідження ціннісних орієнтацій показали, що в процесі національної самоідентифікації студентської молоді провідну роль відіграють: 1) цінності-ідеали (в порядку частоти згадування тут і далі): мир; свобода; добробут, достаток; благополуччя своєї країни; незалежність; 2) цінності-норми: дотримуватися законів; бути патріотом; знати свої права; захищати свою країну; бути чесним; працювати; любити і поважати свою Батьківщину, батьків, родичів, друзів; виконувати свої обов'язки; бути відданим державі; поважати українську культуру; 3) цінності-цілі: розвивати державу; бути незалежним; бути щасливим; бути вільним; жити в достатку; мирне життя; самовдосконалення; жити в безпеці; 4) цінності-засоби: конкретні добрі справи для того, щоб країна стала кращою; усе для свого благополуччя, але те, що не шкодить іншим; робити свою справу, роботу добре.

Також встановлено, що в процесі громадянської самоідентифікації студентської молоді провідну роль відіграють: 1) цінності-ідеали (в порядку частоти згадування тут і далі): мир; незалежність; стабільність; розвинена держава; почуття захищеності; висока якість життя; гідна заробітна платня; 2) цінності-норми: законослухняність; знання законів, своїх прав; турбота про себе і своїх близьких; праця на благо країни; 3) цінності-цілі: самовдосконалення; самореалізація; законність; позитивна динаміка економічного та соціального розвитку; щасливе майбутнє; вдосконалення умов життя в країні; перемога над ворогами; патріотизм; 4) цінності-засоби: робити свою справу якісно; усе на благо держави; те, що не суперечить законам; щось добре для співгромадян; тільки чесні вчинки; поступ до саморозвитку.

Як бачимо, найменш чітке уявлення у молоді як українців і громадян - саме про засоби досягнення цілей.

Щоб визначити основні комунікативні бар'єри, які виникають у процесі національної та громадянської самоідентифікації молоді, ми провели спеціальне емпіричне дослідження. Провідним методом дослідження було глибинне інтерв'ю. Для створення гайду враховувалися методологічні напрацювання Р. Мертона, М. Фіске, П. Кендалла [7], О. Соснюка [8-10] щодо використання цього методу в дослідницькій практиці.

Нами було створено та апробовано гайд глибинного інтерв'ю із застосуванням проективних технік “Вільні асоціації”, “Експерт з виховання” та методики “Креативний простір” для з'ясування особливостей 
вияву різних типів комунікативних бар'єрів національної та громадянської самоідентифікації, можливих способів їх подолання. Дослідження на основі використання глибинного інтерв'ю проводилося протягом 2016-2017 років серед студентів вищих навчальних закладів м. Києва. Аналіз результатів дослідження дав змогу визначити критерії класифікації комунікативних бар'єрів громадянської та національної самоідентифікації молоді: соціальна належність партнерів по спілкуванню, медіакомпетентність, особистісні риси, зміст спілкування, способи та засоби спілкування.

Також нами було уточнено типологію комунікативних бар’єрів національної та громадянської самоідентифікації:

1) соціальні - зумовлені соціальною належністю партнерів по спілкуванню та соціокультурними чинниками;

2) інформаційно-ідеологічні - спричинені особливостями сприймання інформаційних повідомлень та ідеологем у медіапросторі;

3) індивідуально-психологічні - пов'язані 3 особистісними рисами, а також невідповідністю особистісно значущих смислів соціальним вимогам;

4) змістові - залежні від тематики і спрямованості спілкування особистості, а також від адекватності розуміння змісту спілкування його учасниками;

5) операціональні - спричинені вибором способів і засобів спілкування.

Визначено індикатори комунікативних бар'єрів національної та громадянської самоідентифікації залежно від їхнього типу:

- соціальні - знижена готовність до спілкування та конструктивної взаємодії з представниками певних соціальних груп;

- інформаційно-ідеологічні - спотворене сприймання інформаційних повідомлень у медіапросторі;

- індивідуально-психологічні - міжособові конфлікти в спілкуванні та уникання взаємодії;

- змістові - викривлення смислів та неадекватне розуміння змісту спілкування його учасниками;

- операціональні - спотворений зворотний зв’ язок у спілкуванні або брак такого зв’язку.

На основі аналізу результатів емпіричного дослідження визначено основні види комунікативних бар'єрів, які, на думку досліджуваних, виникають у процесі національної самоідентифікації. Зокрема, ми з'ясували, що основними комунікативними бар'єрами національної самоідентифікації молоді є: 1) агресивна патріотична пропаганда (має нав'язливий характер та ображає почуття представників інших національностей, тому дає зворотний ефект і не викликає очікуваних патріотичних почуттів); 2) брак національної ідеї, яка об’єднала б усіх навколо 
себе, невизначеність місії українців як нації (зазвичай використовуються гасла приєднання до когось: “ідемо в Європу”, “приєднуємося до Митного союзу” тощо); 3) неналежна мовна і культурна політика, ії неграмотне проведення (зазвичай вона або не має ефекту взагалі, або ефективна тільки для певних категорій громадян, переважно старшого віку); 4) перекручування історії (неправдиве висвітлення історичних подій, що принижує українців як націю); 5) радянський менталітет (ностальгія за радянським минулим, бажання його повернути та відмова ідентифікувати себе як українця); ворожа пропаганда (таке висвітлення подій в іноземних 3МI, що транслюються в Україні, за якого українці завжди виглядають непривабливо); 6) особливості сімейного виховання (брак національних культурно-історичних традицій виховання); 7) релігійна розрізненість (належність до іншої релігії, що заважає ідентифікувати себе як українця); 8) комплекс меншовартості, або "молодшого брата" (інші нації сприймаються як успішніші, як більш привабливий об’ єкт ідентифікації); 9) глобалізація, космополітизм (усвідомлення себе перш за все “людиною без нації, “громадянином світу”); 10) мовний бар'єр (у різних значеннях: а) вимога ділового спілкування державною мовою сприймається як обмеження права спілкуватися рідною мовою, наприклад російською; б) почуття сорому через спілкування рідною мовою - соромно спілкуватися українською, тому переходять на російську; в) неможливість спілкуватися українською мовою в російськомовному середовищі або навпаки тощо).

Водночас аналіз результатів емпіричного дослідження дав змогу визначити основні види комунікативних бар'єрів, які, на думку респондентів, виникають у процесі громадянської самоідентифікації молоді: 1) непривабливий образ держави (не викликає бажання бути громадянином України); 2) правовий нігілізм (усталена практика не керуватися нормами права в нашій державі); 3) правова некомпетентність (спричиняє брак громадянської відповідальності); 4) політикоідеологічні розбіжності (нерозуміння та неприйняття політики державної політики); 5) морально-виховний бар'єр (невиробленість традицій виховання правової самосвідомості).

Створено методику для виявлення референтних груп сучасної молоді. У ході розроблення методики, спрямованої на виявлення референтних груп, ми спиралися на такі теоретико-методологічні положення: 1) про референтну групу як значущу соціальну детермінанту норм та цінностей, що регулюють поведінку особистості, $\epsilon$ еталоном оцінювання себе та інших; 2) про провідні ознаки референтної групи, такі як вплив на особистість та допомога в реалізації життєвих цілей [11].

Дослідження референтних груп молоді проводилося протягом 2017 р. у вищих навчальних закладах м. Києва серед студентів, які навчаються за спеціальностями технічного, природничого та гуманітарного 
профілів (загальний обсяг вибірки - 130 осіб, з них 72 особи жіночої статі та 58 - чоловічої).

Виявлено підсистеми соціальної взаємодії, в яких відбувається процес самоідентифікації молоді: 3 найближчим соціальним оточенням (друзями); з одногрупниками; з родиною; з викладачами; з друзями 3 інших країн; із соціальними медіа (соцмережами: Facebook, Instagram, Telegram, Twitter); з традиційними медіа (новини в інтернеті, телевізійні новини); з культурно-мистецькими творами (літературними і музичними) та їх виконавцями (акторами та персонажами кінематографа, музикантами, танцівниками).

Встановлено міру впливу референтних груп на процес національної та громадянської самоідентифікації: найбільший вплив мають найближче соціальне оточення (друзі), соціальні медіа (соцмережі), родина та культурно-мистецькі твори, меншою мірою впливають одногрупники та група в цілому, традиційні медіа, викладачі та друзі з інших країн.

Створено репертуарні рангові решітки для дослідження домінуючих бар'єрів національної та громадянської самоідентифікації молоді в різних підсистемах соціальної взаємодії. Домінуючі бар'єри національної та громадянської самоідентифікації молоді досліджувалися протягом 2017-2018 років у вищих навчальних закладах м. Києва серед студентів, які навчаються за спеціальностями технічного, природничого та гуманітарного профілів (загальний обсяг вибірки - 150 осіб, з них 88 осіб жіночої статі і 62 - чоловічої).

За результатами аналізу рангових репертуарних решіток визначено домінуючі бар'єри національної самоідентифікації: 1) у підсистемі “Я - друзі” - брак національної ідеї; глобалізація, космополітизм; 2) у підсистемі "Я - родина" - радянський менталітет; брак національної ідеї; 3) у підсистемі " $Я$ - одногрупники" - брак національних культурноісторичних традицій виховання; мовний; 4) у підсистемі "Я - друзі з інших краӥн” - належність до іншої релігії; мовний бар'єр; брак національної ідеї; 5) у підсистемі “Я - викладачі” - мовний бар'єр; радянський менталітет; 6) у підсистемі “Я - соціальні медіа" - ворожа пропаганда; неправдиве висвітлення історичних подій; неналежна мовна та культурна політика; комплекс меншовартості; 7) у підсистемі “Я традииійні медіа” - агресивна патріотична пропаганда; неправдиве висвітлення історичних подій; ворожа пропаганда; 8) у підсистемі “Я культурно-мистецькі твори” - агресивна патріотична пропаганда; неправдиве висвітлення історичних подій; ворожа пропаганда; мовний бар'єр.

Названо також домінуючі бар'єри громадянської самоідентифікації: 1) у підсистемі "Я - друзі" - політико-ідеологічні розбіжності; морально-виховний; 2) у підсистемі “ $Я$ - родина" - політико-ідеологічні розбіжності; 3) у підсистемі “Я - одногрупники” - морально-виховний; 
правова некомпетентність; непривабливий образ держави; 4) y niдсистемі “Я - друзі з інших країн” - непривабливий образ держави; правовий нігілізм; політико-ідеологічні розбіжності; 5) у підсистемі “Я - соціальні медіa” - правовий нігілізм; морально-виховний; 6) у підсистемі “Я традиційні медіа” - правова некомпетентність; непривабливий образ держави; 7) у підсистемі “Я - культурно-мистецькі твори” - непривабливий образ держави; правовий нігілізм.

Зазначені комунікативні бар'єри можуть бути трансформовані за рахунок розвитку рефлексивних механізмів соціальної взаємодії в умовах тренінгу, що сприятиме становленню національної та громадянської самоідентифікації молоді. Запропоновано технологічну схему подолання комунікативних бар'єрів національної та громадянської самоідентифікації: шляхом їх актуалізації (технологї̈ діагностики: розпізнавання бар'єрів, визначення їхнього впливу на самоідентифікацію, визначення референтних груп впливу на самоідентифікацію), рефлексії (рефлексивні технології: оцінка багатоплановості виявів у підсистемах соціальної взаємодії, визначення зон комфорту/дискомфорту, оцінка адекватності власної поведінки, рефлексія можливих стратегій поведінки), трансформування в різних підсистемах соціальної взаємодії (технології перетворення: створення мотивації до трансформації власного комунікативного досвіду, оволодіння вміннями та навичками оптимізації міжособової взаємодії) та інтеграції досвіду (технології концептуалізації досвіду: закріплення мотивації до аутокорекції і трансформації набутого досвіду, розвиток готовності застосовувати нові знання, вміння, навички в реальній взаємодії).

\section{Висновки}

1. Визначено змістові характеристики національної та громадянської самоідентифікації молоді, афективні і конативні особливості особистісної самоідентифікації та когнітивні, афективні і конативні особливості групової самоідентифікації.

2. Досліджено ціннісні орієнтації, що є регулятором національної та громадянської самоідентифікації молоді, а саме: 1) цінності-ідеали (бажання); 2) цінності-норми (зобов’язання); 3) цінності-цілі (прагнення); 4) цінності-засоби (способи досягнення). Встановлено, що найменш чітке уявлення у молоді як українців і громадян - саме про засоби досягнення цілей.

3. 3'ясовано основні види, типи, критерії та індикатори класифікації комунікативних бар'єрів громадянської та національної самоідентифікації молоді.

4. Виявлено підсистеми соціальної взаємодії, в яких відбувається процес самоідентифікації молоді: 3 найближчим соціальним оточенням (друзями); $з$ одногрупниками; 3 родиною; 3 викладачами; 3 друзями 3 інших країн; із соціальними медіа (соцмережами); з традиційними медіа; з культурно-мистецькими творами. 
5. Встановлено міру впливу референтних груп на процес національної та громадянської самоідентифікації: найбільший вплив має найближче соціальне оточення (друзі), соціальні медіа (соцмережі), родина та культурно-мистецькі твори, меншою мірою впливають одногрупники, традиційні медіа, викладачі та друзі з інших країн. Визначено домінуючі бар'єри національної та громадянської самоідентифікації молоді в різних підсистемах соціальної взаємодії.

6. Запропоновано технологічну схему подолання комунікативних бар'єрів національної та громадянської самоідентифікації: шляхом їх актуалізації, рефлексії і трансформування в різних підсистемах соціальної взаємодії.

Перспективи подальших досліджень полягають в апробації технологічної схеми активізації процесів національної та громадянської самоідентифікації молоді.

\section{Список використаних джерел}

1. Духневич, В. М., \& Сіверс, 3. Ф. (2013). Когнітивне спілкування в умовах утрудненої взаємодії та подолання бар'єрів у міжособових комунікаціях та стосунках. В В. П. Казміренко (Ред.), Засади когнітивної психології спілкування. (с. 331-386). Кіровоград: Імекс-ЛТД.

2. Стінберген В. ван (Ред.). (2005). Умови громадянства. Київ: Український центр духовної культури.

3. Эриксон, Э. (1996). Идентичность: юность и кризис. Москва: Прогресс.

4. Leeds-Hurwitz, W. (Ed.). (1995). Introducing social approaches. In Social approaches to communication (p. 3-20). New York: Gilford.

5. Румянцева, Т. В. (2006). Психологическое консультирование. Диагностика отношений в паре. Санкт-Петербург: Речь.

6. Ядов, В. А. (1994). Социальная идентификация в кризисном обществе. Социологический журнал, 1, 35-52.

7. Мертон, Р., Фиске, М., \& Кендалл, П. (2000). Фокусированное интервью. Москва: Институт молодежи.

8. Соснюк, О. П. (2008). Діагностика особливостей особистісної активності суб'єктів інноваційної діяльності якісними методами. Актуальні проблеми психології: збірник наукових прачь Інституту психології ім. Г. С. Костюка АПН України, т. 7, вип. 16, 163-168.

9. Соснюк, О. П. (2011). Проективна методика "Креативний простір" як психодіагностичний та дослідницький інструмент. Вісник Харківського начіонального університету імені В. Н. Каразіна, 971, 145-151.

10. Соснюк, О. П. (2012). Психосемантична інтерпретація візуальних образів у прикладних дослідженнях. Наука і освіта. Тематичний спецвипуск: “Когнітивні процеси та творчість", 9, 201-205.

11. Tajfel, H., Figment, C, Billig, M., \& Bundy, R. (1971). Social categorization and intergroup behaviour. European Journal of Social Psychology, 1, 149-177.

\section{References}

1. Dukhnevych, V. M., \& Sivers, Z. F. (2013). Kohnityvne spilkuvannia v umovakh utrudnenoi vzaiemodii ta podolannia barieriv u mizhosobovykh komunikatsiiakh 
ta stosunkakh [Cognitive communication in complicated interactions and overcoming barriers in interpersonal communication and relationships]. In V. P. Kazmirenko (Ed.), Zasady kohnityvnoi psykholohii spilkuvannia [Principles of cognitive psychology of communication] (p. 331-386). Kirovohrad: ImeksLTD Publ. (ukr).

2. Stinbergen V. van (Ed.). (2005). Umovy hromadianstva [The conditions of citizenship] (p. 49-70). Kyiv: Ukrainskyi Tsentr dukhovnoi kultury (ukr).

3. Erikson, E. (1996). Identyichnost: yunost $i$ krizis [Identity youth and crisis]. Moscow: Progress Publ. (rus).

4. Leeds-Hurwitz W. (Ed.). (1995). Introducing social approaches. Social approaches to communication (pp. 3-20). New York: Gilford.

5. Rumyantseva, T. V. (2006). Psikhologicheskoye konsultirovaniye: diagnostika otnosheniy v pare [Psychological counseling: diagnosis of relationships in couples]. St.-Petersburg: Rech Publ. (rus).

6. Yadov, V. A. (1994). Sotsialnaya identifikatsiya v krizisnom obshchestve [Social identification in a crisis society]. Sotsiologicheskiy zhurnal [Sociological journal], 1, 35-52 (rus).

7. Merton, R., Fiske, M., \& Kendall, P. (2000) Fokusirovannoye intervyu [The focussed interview]. Moscow: Publishing House of the Instityte of Youth (rus).

8. Sosniuk, O. P. (2008). Diahnostyka osoblyvostey osobystisnoi aktyvnosti subiektiv innovatsiinoi diialnosti yakisnymy metodamy [Diagnostics of peculiarities of personal activity of subjects of innovative activity by qualitative methods]. Aktualni problemy psykholohii. Zbirnyk naukovykh prats Instytutu psykholohii imeni H. S. Kostiuka APN Ukrainy [Actual problems of psychology], vol. 7, is. 16, 163-168 (ukr).

9. Sosniuk, O. P. (2011). Proektyvna metodyka "Kreatyvnyi prostir" yak psykhodiahnostychnyi ta doslidnytskyi instrument [Projective technique "Creative space" as a psycho-diagnostic and research tool]. Visnyk Harkivskoho natsionalnoho universytetu imeni $V$. N. Karazina [Bulletin of Kharkiv National University named after V. N. Karazin], 971, 145-151 (ukr).

10. Sosniuk, O. P. (2012). Psykhosemantychna interpretatsiia vizualnykh obraziv u prykladnykh doslidzhenniakh [Psychosemantic interpretation of visual images in applied research]. Nauka i osvita [Science and education], 9, 201- 205 (ukr).

11. Tajfel, H., Figment, C, Billig, M., \& Bundy, R. (1971). Social categorization and intergroup behaviour. European Journal of Social Psychology, 1, 149-177.

(C) Остапенко I. B. 